International Journal of Physical Research, $9(1)(2021) 1-6$
International Journal of Physical Research
SPC
Website: www.sciencepubco.com/index.php/IJPR
Research paper

\title{
The thermodynamic principles as the theoretical basis of fair remuneration
}

\author{
Mieczysław Dobija ${ }^{1}$, Jurij Renkas ${ }^{1}$ \\ ${ }^{1}$ Department of Accountancy, Cracow University of Economics, Rakowicka St., 27, 31-425, Cracow, Poland \\ *Corresponding author E-mail: dobijam@uek.krakow.pl
}

\begin{abstract}
Thermodynamics is the key to solving many economic problems. Since the human body is driven by heat engines, there is a loss of energy source. Measuring this loss means it is possible to indicate the size of a fair wage. Another version of the second principle justifies the amount of depreciation of real assets, such as machinery and equipment. A significant purpose of the article is to indicate that the category of capital cannot be understood without knowing the first and second principle of thermodynamics. The main aim is to present the theory of equitable remuneration developed using the second principle of thermodynamics and the discovered economic constant. Theoretical research leads to the creation of a model of capital and a model of fair pay with the understanding of the existence of an economic constant quantifying the action of natural forces on capital growth. Empirical research estimates the size of the constant and verifies the fairness of remuneration. The research reveals the existence of an economic constant necessary in capital theory, especially in the field of remuneration for work. Models for measuring human capital of employees and formulas enabling calculation of fair remuneration and its updating are presented. Additionally, using the entropic version of the second principle, the depreciation amounts of fixed assets are determined. The main conclusion of the presented research and the formulated theory is that thermodynamics is essential for the correct understanding of the category of capital defining as the abstract ability to perform work.
\end{abstract}

Keywords: Thermodynamic; Economic Constant; Fair Remuneration; Capital; Natural Science; Economic Science.

\section{Introduction}

Two basic physical principles and the main identity of accounting are at the basis of the considerations presented in this article. These are the first and second principles of thermodynamics and an accounting equation that equates the value of assets and total capital. In economics, the principle of minimum action is commonly used, but in this paper we do not stress its importance. The second principle of thermodynamics, indicating that a thermal engine cannot work without a cooler, is the basis of the presented theories of fair remuneration for work. The fairness of the remuneration consists in the fact that the personal capital of the employee is not depreciated, because the remuneration eliminates the dispersion. Therefore, the essence of the research is to measure the dispersion of human capital, because the employee's body acts as a heat engine. Therefore, compensating the loss of capital in the form of remuneration prevents depreciation of the employee's human capital, and additional remuneration from profits makes it possible to improve living conditions. This is the essence of fair remuneration, and empirical studies confirm this opinion. Moreover, the average value of the random variable of the spontaneous loss of human capital turns out to be a natural economic constant, necessary for measuring human capital, determining fair remuneration and various uses of the capital category. The ideas presented are original in relation to the views on the connections between physics and economics known from numerous bibliographies. Authors considering these issues do not take into account the principle of dualism, i.e., the basic identity of accounting theory, and treat capital, abstract in its nature, as material assets. Removing this misunderstanding leads to the direct use of thermodynamics for the development of capital theory, which is the content of the article.

\section{The thermodynamic nature of life}

The human body is powered by thermal engines. We know it and feel it, but theoretical explanations have been offered by William Thomson (Lord Kelvin) and Peter Atkins (2007, pp. 23-78). The first researcher formulated a version of the second law of thermodynamics, according to which a heat engine cannot operate without a cooler; the cooler does not have to be a special device, but simply an environment that fulfills the role of a heat consumer. Peter Atkins reminded us that the human body contains thousands of biochemical reactions acting on the principle of a thermal engine, so during our lives we must lose some energy transferred by heat to the environment. As Atkins (2005, pp. 157-158) explains, "The abstract thermal engine found in our body is diffused between all the cells of our body and takes thousands of different forms". The author explains the action of the thermal engine in our body via the ATP molecule (adesintriphosphate), which converts into adenosine diphosphate, thanks to the enzymes, while releasing energy. Therefore, lost energy must be replenished. Without supplementation, the human ability to work would disappear over time. 
The essence of an honest wage results from the observation that if life requires the operation of thermal engines, and these can work only if part of the source energy is lost, then this loss must be balanced to maintain equilibrium and preserve our own existence. This theoretically deduced statement is confirmed by empirical calculations of the cost of living in a family type $(2+2)$ in which parents earn only the minimum wage. A fair wage must, therefore, balance the natural loss of human capital resulting from the essence of life.

For further consideration this loss is determined by the random variable $\mathrm{s}$, whose average value, according to empirical study, is equal to $\mathrm{E}(\mathrm{s})=0.08$ [1/year]. Moreover the value $\mathrm{p}=\mathrm{E}(\mathrm{s})=0.08$ [1/year] is discerned as an economic constant; a sort of natural constant. This value is necessary both for computing fair pay as well as for computing the value of human capital. Additionally this constant denotes that nature creates the potential for capital growth at an average rate of $8 \%$ per year. Therefore, the general view on compensation can be briefly formulated as:

$\mathrm{W}(\mathrm{p})=\mathrm{p} \times \mathrm{H}(\mathrm{p})$

Where: $\mathrm{W}(\mathrm{p})$ - denotes yearly total pay, $\mathrm{H}(\mathrm{p})$ - value of employee human capital, and $\mathrm{p}=\mathrm{E}(\mathrm{s})=0.08$ [1/year] (Dobija, 1998; Kurek, 2012; Renkas, 2013) and others.

In simple terms, a fair pay is $8 \%$ of the value of human capital of an employee working under self and managerial control. Formula (1), in which the constant $\mathrm{p}$ represents the natural loss of human capital defined by the second law of thermodynamics, is the basic model used to calculate the fair remuneration of employees with capital $\mathrm{H}(\mathrm{p})$.

\section{Model of capital}

Capital is abstract, so only it can be described mathematically using constructive mathematics. The history of getting to know the category of capital formally begins at the end of the 15th century in Italy. In 1494 year a famous book was published in Venice called shortly Summa. This printed book by Luca Pacioli consisted, among others, a description of the fundamental equation of the double entry accounting that represent duality principle. The description begins with accounting identity, which shows that at moment zero:

Value of Assets $\left(\mathrm{A}_{0}\right)=$ Debt capital $\left(\mathrm{D}_{0}\right)+$ Equity capital $\left(\mathrm{E}_{0}\right)$

Skipping owners' rights to capital the above equation can be introduced with total capital $\left(\mathrm{C}_{0}=\mathrm{E}_{0}+\mathrm{D}_{0}\right)$ in the simplest way as follows:

$\mathrm{A}_{0}=\mathrm{C}_{0}$

Directly from the identity (3) results that capital is an abstract category denoting ability of performing work. It represent potential of mentioned ability included in assets that are formed from material substances. Concentration of capital embodied in the assets determines value of the assets, so capital is of the most importance. Increasing capital is the goal of economic activities. Periodical increase of capital in business firms is called income.

In contrast to this natural report about capital, after ages of studies, economists attain to conclusion clearly expressed by Ch. Bliss. This author in 1975 year wrote that "(...) when economists reach agreement on the theory of capital they will shortly reach agreement on everything. Happily, for those who enjoy a diversity of views and beliefs, there is very little danger of this outcome. Indeed, there is at present not even agreement as to what the subject is about" (Bliss Ch., Cohen A.J. \& Harcourt G.C. (eds.), 2005).

When we consider the basic indicator (return on assets, ROA) $r=R O A=\Delta C / C_{0}$, we come to a compound percentage formula (4) as well to a model showing non-linear growth of capital. It is known that $\mathrm{C}_{1}=\mathrm{C}_{0}\left(1+\mathrm{r}_{1}\right)$, and in the following year will be $\mathrm{C}_{2}=\mathrm{C}_{0}\left(1+\mathrm{r}_{1}\right)\left(1+\mathrm{r}_{2}\right)$ unless the capital is withdrawn. Assuming that there are some averages $r$ is given the general formulas:

$\mathrm{C}_{\mathrm{n}}=\mathrm{C}_{0}(1+\mathrm{r})^{\mathrm{n}} \quad \mathrm{C}_{\mathrm{t}}=\mathrm{C}_{0} \mathrm{e}^{\mathrm{rt}}$

The second formula presents a situation in which the capital is constantly growing, not as a percentage added at the end of the year. This is the basic model of growth, which is consistent with the principle that capital does not come from nothing. This model provokes the question about the variable $r$, about the explanation of the nature and structure of this quantity. This is one of the important issues in accounting, economics and finance.

Albert Einstein expressed his admiration for the compound percentage formula and, showing a deeper interest, he presented Rule 72 . Probably, the appreciation would have been greater with the knowledge of the structure of the capital growth rate $\mathrm{r}=\mathrm{p}-\mathrm{s}+\mathrm{m}$, which identifies and quantifies the influences of natural forces, work, and the second principle of thermodynamics.

According to the second law of thermodynamics (SLOT), capital is randomly dispersed (factor $\mathrm{e}^{\text {-st }}$ ). However, this distraction can be inhibited and limited by work processes (factor $\mathrm{e}^{\mathrm{mt}}$ ). We paint the metal sheet with paint and rust will not destroy the windowsill as quickly as if it had happened without painting. Due to the nature of work, which is only a transfer of capital, work does not increase capital. However, profits do arise, so there must be one more factor. They are forces of nature, like photosynthesis, which are quantified by the economic constant $\mathrm{p}$ (factor $\mathrm{e}^{\mathrm{pt}}$ ). Thus, the general model of capital change is:

$\mathrm{C}_{\mathrm{t}}=\mathrm{C}_{0} \times \mathrm{e}^{-\mathrm{st}} \times \mathrm{e}^{\mathrm{mt}} \times \mathrm{e}^{\mathrm{pt}}$, and $\mathrm{p}=\breve{\mathrm{E}}(\mathrm{s})=0,08[1 /$ year $]$

Where: $\breve{E}(s)$ - average value of random variable s, p - economic constant of potential growth of capital. The constant p has no explanatory theory, so its size results from empirical research. As the model (5) indicates, if the work completely eliminates the influence of SPoT, the annual growth rate of capital in business activities is $8.33 \%$. The constant is an a priori figure of 0.08 , which is verified by empirical studies. Research of nature of capital and size of constant have been already made by many authors as: M. Dobija (2007), B. Kurek (2011, 2012) and J. Renkas (2016) and they are continued over and over again presenting new confirmations of the magnitude of this constant. The research conducted by B. Kurek (2012), who used large sets of data, leads to the conclusion that the yearly average value of a ratio of profit to total capital (ROA) is pretty stable and close to eight percent. The interpretation that comes to mind is that economics is a positive-sum game with nature, expressed by the constant $p$.

There are two great domains where the abstract ability of performing work is of the greatest importance. As P. Atkins (2007) explains it is physics, where ability of doing work (energy) is a core notion. Similarly to this fact it is economics and accounting, where capital is a 
basic category. Therefore, we can better understand concepts of capital and labor and correctly solve scientific problems. For example problem of depreciations of fixed assets. The application of the SLoT in the entropic form immediately leads to a theoretically justified calculation of fixed asset depreciation amounts as follows:

$\mathrm{W}_{\mathrm{p}} \times \mathrm{e}^{-\mathrm{d} \times \mathrm{t}}=\mathrm{W}_{\mathrm{k}}$

Where: $\mathrm{W}_{\mathrm{p}}$ - initial value of the object, $\mathrm{W}_{\mathrm{k}}$ - value at the end of the period, $\mathrm{t}$ - number of periods, $\mathrm{d}$ - fixed percentage depreciation of the fixed asset in the period. When calculating the fixed amount d you get the percentage that determines the depreciation amount from the current balance. The figure $d$ can be expressed in terms of months or years. Moreover, the formula allows for theoretically justified forecasting of the value of a fixed asset for any given date.

The application of the SLoT as a rule defining the operating conditions of a thermal engine, and consequently the inevitable loss of energy of the source, applies directly to a human being. This source of energy is food, but in order to consume it one needs a properly equipped apartment. In order to get everything we need for ourselves and our offspring we have to work, so naturally the issue of decent remuneration for work arises. Research in this area has led to the identification of the aforementioned constant, so both the fundamental principle and the economic constant are inherent in the human capital computations, which is explained further in the article.

Capital and labor are by definition tightly tied up. They are interdependent categories forming tandem. Labor is present in definition of capital and vice verse. Capital is a potential category, whereas labor is a dynamic one. Labor as transfer of capital has a strong relationship with power (labor $=$ power $\times$ time of labor). Category of power has been always present in economics since list of labor positions in a company or institution differs mainly by rate of pays. The pays divided by the highest pay denote power indexes assigned to work positions.

\section{Human capital measurement and models of pays}

The formula applied in physics for measuring work, presented in a simplified scalar notation, shows two equivalent models. In this simplified scalar description, the measure of labor is:

$\mathrm{L}=\mathrm{F} \times \mathrm{s} \times \cos \varphi=\mathrm{F} \times \mathrm{V} \times \mathrm{t} \times \cos \varphi=\mathrm{P} \times \mathrm{t} \times \cos \varphi$

Where: $\mathrm{L}$ - scalar mechanical work; $\mathrm{F}$ - scalar force; $\mathrm{v}$ - speed scalar; $\cos \varphi$ - cosine of the angle between the direction of force and the direction of movement; $\mathrm{P}$ - scalar of power; and $\mathrm{t}$ - time of completion of work.

In economic practice, particularly in employment contracts, commonly, though perhaps unconsciously, the formula containing the second part of equation (7) is applied with the category of power and the passage of time. Assigning an employee a rate of payment due to assigned responsibilities or positions in jobs is the determination of the potential power (P). If an employee is assigned to a position paying USD3,000, and the highest salary is USD15,000, the power factor is $1 / 5$ and 180 hours of work per month, which is equal to $(1 / 5 \times$ $180=36$ ) units of labor. By this account, 36 labor units = USD3,000, so USD1 $=0.012$ basic units of labor. It does not matter in the economy what part of the 1 labor unit is USD1. This unit is adopted as the basis of economic calculations; the dollar is just a common unit of labor. Since the power coefficient is determined as the quotient of wages, and $(\mathrm{W}=\mathrm{p} \times \mathrm{H})$ the measurement of labor in the economy can be described as follows:

$\mathrm{L}=\mathrm{P} \times \mathrm{t} \times \cos \varphi=\mathrm{W} / \mathrm{W}_{\max } \times \mathrm{t} \times \cos \varphi=\mathrm{H} / \mathrm{H}_{\max } \times \mathrm{t} \times \cos \varphi$

Where: $\mathrm{W} / \mathrm{W}_{\max }$ denotes individual wages, and $\mathrm{H} / \mathrm{H}_{\max }$ denotes the personal human capital of examined employees. The self-control of an individual and managerial control make it possible to assume that $\cos \varphi$ is equal to 1.0.

Measuring employee's human capital involves all layout indispensable costs in order for an individual to achieve the planned ability to work. Since a baby is a natural good and does not rely on economic calculations, we compute the future value of the cost of life and the cost of professional education. Then the total is enlarged by the capital generated by professional experience. Thus, the simplest model of employee human capital is as follows:

$\mathrm{H}(\mathrm{T})=(\mathrm{K}+\mathrm{E})[1+\mathrm{Q}(\mathrm{T})]$

Where: $\mathrm{H}(\mathrm{T})$ - value of employee human capital with $\mathrm{T}$ years of professional experience, $\mathrm{K}$ - capitalized value of living cost at the rate $\mathrm{p}$ at the start of a professional career ( $\mathrm{n}$ years), $\mathrm{E}$ - capitalized value of the cost of a professional education at the rate $\mathrm{p}$ by $\mathrm{m}$ years, $\mathrm{T}-$ years of professional experience, $\mathrm{Q}(\mathrm{T})$ - the value of the adjusted learning curve with parameter $\mathrm{w}$. Now it is easy to see that formula (9) can be reshaped to the additive form (10) as follows:

$H(T)=(K+E)[1+Q(T, w)]=K+E+D(T), D(T)=H(0) \times Q(T, w) \quad Q(T)=1-T^{\left[\frac{\ln (1-w)}{\ln 2}\right]}$

Where w represents the ability to learn. Since each factor K, E, D (T) deserves at least $8 \%$ as pay, one can construct a compensation system considering the law of demand and other coherent thinking. Factor D $(\mathrm{T})$ determines experience capital. If $\mathrm{w}=0.05$, it means an employee does the same work in the following year 5\% easier and cheaper.

Considerations stimulated by discerning the human body as a thermal engine led to the conclusion that an employee's pay with human capital $\mathrm{H}(\mathrm{T})$ should be established as a percentage of human capital $(\mathrm{p} \times \mathrm{H}(\mathrm{T}))$, where $\mathrm{p}=8 \%$ (Formula 1). This refers to the concept of constant in economic sciences.

\section{Selected empirical studies on the economic constant}

It follows from the considerations presented above that respecting the fundamental principles brings economic sciences closer to the natural sciences. The presence of the constant deserves special attention. Below are shown the five selected empirical studies on the economic constant, which confirmed its presence in economic sciences: 
1) The economic constant can also be identified and measured on the basis of data on periodic earnings and returns on stocks. Such research has previously been done in assessing "risk premium" by researchers. This amount, defined as the difference between the real rate of return and return on Treasury Bills in the USA, is among others, a component of the model CAPM (Goetzmann \& Ibbotson, 2006). It is matter of fact that CAPM deteriorates its value at the present time. What is new in the approach of the research on "risk premium" presented below is that we are aware of the economic constant and natural forces with which the "risk premium" is associated. Income on an efficient market are the result of, among others, the action of natural forces. After all, raw material was paid, employees received their wages (costs), depreciation of fixed assets also increased costs, so it is possible that the forces of nature are the source of periodic increase in invested capital. Therefore, the value of economic constant of potential growth is assessed as a real rate of return achieved in an effective market (Table 1).

Table 1: Cumulative Statistics for Rates of Return on Stocks, Bonds and Treasury Bills in USA (1926-2004)

\begin{tabular}{lllll}
\multicolumn{5}{c}{ Table 1: Cumulative Statistics for Rates of Return on Stocks, Bonds and Treasury Bills in USA (1926-2004) } \\
\hline Specification & Stocks & $\begin{array}{l}\text { Long-Term Govern- } \\
\text { ment Bonds }\end{array}$ & Treasury Bills & Inflation \\
\hline Arithmetic average & $12.39 \%$ & $5.82 \%$ & $3.76 \%$ & $3.12 \%$ \\
Geometric average & $10.43 \%$ & $5.44 \%$ & $3.72 \%$ & $3.04 \%$ \\
Standard deviation & $20.31 \%$ & $9.30 \%$ & $3.14 \%$ & $4.32 \%$ \\
\hline
\end{tabular}

Search: own study based on data taken from (Goetzmann, Ibbotson, 2006, p. 35).

To calculate the rate of return based on the data in Table 1, the percentage of inflation was subtracted from the return on stocks, which gave the value: $12.39-3.12=9.27 \%$ calculated according to the arithmetic average. Whereas, according to the geometric average it is $10.43-3.04=7.39 \%$. This range (7.39-9.27) includes the average long-term rate of return achieved on the American capital market. To arrive to score was calculated the arithmetic mean of these two numbers and was obtained a value of $8.285 \%$. For stock market and reporting corporate profits, the data indicates the value at the end of the accounting year. Therefore, if capital grows at the rate of $8 \%$ (ex ante), then at the end of the year (ex post) it reaches level $\mathrm{e}^{0.08}-1$, which is about $8.33 \%$. Thus, the estimation specifies $p=0.08$ [1/year].

2) Rates of return on invested capital in business entities were tested by B. Kurek (2012). His research was particularly concerned the rate of capital increase in entrepreneurship. The survey was conducted on a sample of financial statements of companies belonging to the Standard \& Poor's 1500 further period of 20 years. The component parts of the index were taken into account, i.e. companies grouped in indices: Standard \& Poor's 1000, Standard \& Poor's 900, Standard \& Poor's 600, Standard \& Poor's 500, Standard \& Poor's 400 . The total number of observations obtained was 22,952 . The results of statistical research confirmed the hypothesis about the average value of the risk premium ex post in the dimension of $8.33 \%$, which corresponds to the $8 \%$ risk premium ex ante. The study was conducted at a confidence level of 0.999 , obtaining a confidence interval of $8.25-8.89 \%$, with the average being $8.57 \%$. Statistical inference was considered completely safe due to low relative random error (3.75\%).

3) Also, the existence of the economic constant was examined on the basis of wage expectations in Ukraine. Estimating the constant was done on data that comes from five different regions of Ukraine. Surveys were prepared obtaining data from Governmental Offices for job seekers. 3,920 people were surveyed by asking about expected earnings and collecting data necessary for calculating the value of human capital. Choosing place for collecting the research data for survey was dictated by the fact that the job seeker does not exhibit excessive expectations, but they take into regard mainly their costs of living.

The survey contained 5 questions about: gender; age; education; work experience and expected pay in the event of employment. This information constituted the basis for estimating the value of human capital of the respondents. Converting the model (1) to the form $p=W_{U} / H_{(p)}$, where $\mathrm{W}_{U}$ presents the value of the expected remuneration, a basic equation was obtained, into which substituting the expected remuneration $\left(\mathrm{W}_{\mathrm{U}}\right)$ and the estimated value of human capital of the respondents $(\mathrm{H}(\mathrm{p}))$ were determined the size of the average value of constant $\mathrm{p}$ from the survey data set. The obtained calculation results are presented in Table 2.

Table 2: The Results of Statistical Calculations of the Average Value of Constant P (Confidence Level - 0.999)

\begin{tabular}{llllll}
\multicolumn{7}{c}{ Table 2: The Results of Statistical Calculations of the Average Value of Constant P (Confidence Level - 0.999$)$} \\
\hline Statistical quantities & Average value & $\begin{array}{l}\text { Lower confidence } \\
\text { val value }\end{array}$ & $\begin{array}{l}\text { Upper confidence inter- } \\
\text { val value }\end{array}$ & Standard deviation & Median \\
\hline The constant $\mathrm{p}$ & 0.079977 & 0.079702 & 0.080252 & 0.005237 & 0.079658 \\
\hline
\end{tabular}

As can be seen from Table 2 in the group of 3,920 respondents the average value of $\mathrm{p}$ in the light of wage expectations is at a level close to 0.08. It is also worth mentioning that a similar study of the size of the economic constant was carried out by W. Kozioł (2011), who, on the basis of the human capital account and the analysis of wages of a large number of employees in a Polish enterprise, statistically confirmed its size at the level of $8 \%$.

4) 4) Established laws also are area in which the constant p manifests itself. According to A. Pikulska-Robaszkiewicz (1999, pp. 4142) in the Republic of Rome the interest rate on granting a loan was legally limited and defined as 1/12 of capital, i.e. $8.33 \%$ per annum. Maintaining this limitation, Emperor Justinian freed contracts from unjustified ruining percentage. This decision was a reasonable compromise between humanitarianism and the necessary needs of trading, which revealed the effect of the natural rate of capital multiplication. Later, the introduction of a similar limit for interest on maritime loans enabled the development of maritime trade.

5) 5) The actual minimum wage in the USA confirms the existence of the economic constant. The minimum wage is due to a person without professional education and experience. In the case of the human capital for person without professional education and professional experience (for example for a 17-year-old) the model (9) will be presented like: $H(p)=K(p)$, which means that we take into account only the capitalized cost of living. Capitalized cost of living $\mathrm{K}(\mathrm{p})$ is determined using continuous capitalization and as demonstrated at (Renkas, 2017) $\mathrm{K}(\mathrm{p})=\mathrm{k}(\mathrm{ept}-1) / \mathrm{p}$. This model determines the value of the absolute minimum wage in economy. Hence, on the basis of formula (1), we come to the formula for estimation of constant $p$, which base on real minimum wage:

$\mathrm{W}_{\mathrm{R}}=\mathrm{p} \times \mathrm{K}(\mathrm{p})=\mathrm{p} \times \mathrm{k} \times \frac{e^{\mathrm{pt}}-1}{\mathrm{p}}$

Where: $\mathrm{W}_{\mathrm{R}}$ - real minimum wage, $\mathrm{p}$ - economic constant, $\mathrm{t}$ - number of years, $\mathrm{k}$ - monthly living costs. 
Since the theoretical calculation of a fair minimum wage requires the use of the constant $p$, we will estimate its value using the example of the actual minimum wage in the USA, denoting $\mathrm{p}$ in the above formula as the value sought. The economy of USA was chosen due to the widespread desire to migrate to this country, which indicates the fairness of wages there. The above formula (11) is transforming to the form:

$$
\mathrm{p}=\frac{1}{\mathrm{t}} \ln \left[\frac{\mathrm{W}_{\mathrm{A}}}{\mathrm{k}}+1\right]
$$

Where: $\mathrm{W}_{\mathrm{A}}$ - real minimum wage in USA.

Having determined the estimation formula we can compute the constant $\mathrm{p}$ for several selected states in USA. Public knowledge is that in Washington D.C. beginning July 1, 2020, the minimum wage will increase to USD 15.00 per hour for all workers, regardless of size of employer. Adding $7.65 \%$ of the employer's costs to this amount, we obtain the value of the employee's employment costs. On a monthly basis it is: 176 hours $\times 16.15 \mathrm{USD} / \mathrm{hour}=\mathrm{USD}$ 2.842.4. Monthly living costs $(\mathrm{k})$ in Washington D.C. is estimated at USD848. Thus, assuming for the calculation of a person at age 17 is obtained: $\mathrm{p}=\frac{1}{17} \ln \left[\frac{2,842.4}{848}+1\right]=0.0865$. In other selected states estimation leads to similar results (Table 3).

Table 3: Calculations of the Constant for Selected States (2020)

\begin{tabular}{|c|c|c|c|c|}
\hline City and State & $\begin{array}{l}\text { Family of four estimated monthly } \\
\text { living costs (USD) }\end{array}$ & $\begin{array}{l}\text { Monthly living costs per } \\
\text { person (USD) }\end{array}$ & $\begin{array}{l}\text { Minimum Wage by State } \\
\text { (USD per hour)* }\end{array}$ & $\begin{array}{l}\text { Size of con- } \\
\text { stant } p\end{array}$ \\
\hline Albuquerque, New Mexico & 1,992 & 498 & 9.69 & 0.0875 \\
\hline Anchorage, Alaska & 2,783 & 696 & 10.65 & 0.0769 \\
\hline Baltimore, Maryland & 2,519 & 630 & 11.84 & 0.0859 \\
\hline Boise, Idaho & 2,124 & 531 & 7.80 & 0.0751 \\
\hline Boston, Massachusetts & 3,227 & 807 & 13.73 & 0.0815 \\
\hline Burlington, Vermont & 2,503 & 626 & 11.80 & 0.0861 \\
\hline Cincinnati, Ohio & 2,091 & 523 & 9.37 & 0.0838 \\
\hline Denver, Colorado & 2,898 & 725 & 12.92 & 0.0836 \\
\hline Detroit, Michigan & 2,239 & 560 & 10.39 & 0.0853 \\
\hline Honolulu, Hawaii & 3,079 & 770 & 10.87 & 0.0734 \\
\hline Indianapolis, Indiana & 2,289 & 572 & 7.80 & 0.0720 \\
\hline Jersey City, New Jersey & 3,540 & 885 & 11.84 & 0.0712 \\
\hline Los Angeles, California & 3,161 & 790 & 13.99 & 0.0832 \\
\hline Louisville, Kentucky & 2,108 & 527 & 7.80 & 0.0754 \\
\hline Memphis, Tennessee & 1,959 & 490 & 7.80 & 0.0786 \\
\hline Milwaukee, Wisconsin & 2,223 & 556 & 7.80 & 0.0732 \\
\hline Minneapolis - St. Paul, Minnesota & 2,552 & 638 & 10.77 & 0.0811 \\
\hline Nashville, Tennessee & 2,338 & 585 & 7.80 & 0.0711 \\
\hline New Orleans, Louisiana & 2,338 & 585 & 7.80 & 0.0711 \\
\hline Oakland, California & 3,359 & 840 & 13.99 & 0.0805 \\
\hline Oklahoma City, Oklahoma & 2,025 & 506 & 7.80 & 0.0771 \\
\hline Orlando, Florida & 2,552 & 638 & 9.21 & 0.0744 \\
\hline Phoenix, Arizona & 2,437 & 609 & 12.92 & 0.0914 \\
\hline Portland, Oregon & 2,898 & 725 & 12.11 & 0.0807 \\
\hline Providence, Rhode Island & 2,453 & 613 & 11.3 & 0.0850 \\
\hline Raleigh, North Carolina & 2,289 & 572 & 7.80 & 0.0720 \\
\hline Sacramento, California & 2,766 & 692 & 13.99 & 0.0893 \\
\hline San Antonio, Texas & 2,174 & 543 & 7.80 & 0.0741 \\
\hline San Francisco, California & 3,837 & 959 & 13.99 & 0.0748 \\
\hline San Jose, California & 3,063 & 766 & 13.99 & 0.0846 \\
\hline Seattle, Washington & 3,079 & 770 & 14.53 & 0.0861 \\
\hline Tampa, Florida & 2,550 & 637 & 9.21 & 0.0744 \\
\hline Washington D.C. & 3,392 & 848 & 15.07 & 0.0834 \\
\hline Minimum value & & & & 0.0711 \\
\hline Maximum value & & & & 0.0914 \\
\hline Median & & & & 0.0805 \\
\hline Standard deviation & & & & 0.006 \\
\hline The mean value of the constant $p$ & & & & 0.0795 \\
\hline
\end{tabular}

The results of the calculations contained in Table 3 confirm that the minimum wage in the USA is determined by the constant $\mathrm{p}$, and its value is at a level close to 0.08 [1/year]. The use of a constant in economics allows for the determination of fair values, therefore in terms of wages it is told about fair wages, which eliminates the natural spontaneous dispersion of human capital.

Thus, the statutory minimum wage in the USA is fair, which means, that earnings of two working parents allow the two descendants to reach the level of human capital they achieve, i.e. this wage guarantees the preservation of human capital. This fairness of the minimum wage in the USA is manifested in practice by the desire to migrate to the USA, which is a known fact. Fairness of the minimum wage is confirmed by the calculations made on the average values of living costs and wages. The average living costs is estimated at USD577.00 per month. Parents' earnings are taken at the average minimum wage per hour (from all states) multiplied by 176 hours, i.e.: $2 \times$ USD9.00 per hour $\times 176$ hours = USD3,168.00. After adding 6.2\% Social Security Tax and 1.45\% Medicare Tax paid by the employer, the total family income is USD $3,410.35$. Assuming $20 \%$ on pension fund and $10 \%$ on health care, the income remaining in a family of four is USD2,387.24. Per person will be: USD2,387.24 / 4 = USD596.81, which is more than the average living costs USD577.00 (see computations in the Table 4). 
Table 4: Calculations of the Income Remaining in A Family of Four (2020)

\begin{tabular}{ll}
\hline Item & Calculations \\
\hline Earnings of two parents & $2 \times(9.00$ USD/hour $\times 176$ hours $)=3,168.00$ \\
Contributions paid by the employer & $3,168.00 \times 0.0765=242.35$ \\
$(6.2 \%$ Social Security Tax and $1.45 \%$ Medicare Tax $)$ & $3,410.35$ \\
Total family income & 682.07 \\
$20 \%$ on pension fund & 341.04 \\
$10 \%$ on health care & $2,387.24$ \\
Income remaining in a family of four & $2,387.24 / 4=596.81$ \\
Income remaining in a family per person & 577.00 \\
Average cost of living & \\
\hline
\end{tabular}

This calculations proves that the level of the minimum wage in USA guarantees the preservation of human capital, so examined wages are the fair pay. Thus, the use of economic constant in determining of fair wages leads to the preservation of human capital.

It is also worth noting that some countries apply small decreases of minimum pay at the beginning of a period of work. In relation to formula (9) can compute diminishing minimum pay using a fraction of a year as variable $\mathrm{T}$. The model is $\mathrm{H}(\mathrm{T})=\mathrm{K}(1+\mathrm{Q}(\mathrm{T}))$. So, with $\mathrm{T}=1 / 12$ we obtain the following: $\mathrm{Q}(1 / 12)=1-$ $=1-12^{0.074}=1-1.20$. So $1+\mathrm{Q}(\mathrm{T})=0.8$, where the parameter of learning is assumed to be $12^{\frac{\ln 0.95}{\ln 2}}$

0.05. Thus, assuming average living costs in Washington D.C. at the level of USD848 we get: $\mathrm{H}(1 / 12)=\mathrm{K} \times 0.8=\left(12 \times 848\left(\mathrm{e}^{0.08 \times 17}-\right.\right.$ $1) / 0.08) \times 0.8=$ USD295,058. Therefore, the minimum pay in the first month of work is: $\mathrm{W}=(\mathrm{USD} 295,058 \times 0.08) / 12 \mathrm{mc} / 176 \mathrm{~h}=$ USD11.18 per hour, and it will grow every month. A further question is how this pay grows to $\mathrm{T}=10$ years, assuming the same employee with $\mathrm{w}=0.05$ ? The model is: $\mathrm{H}(10)=\mathrm{K} \times[1+\mathrm{Q}(10)]=368,822 \times 1.1857687=\mathrm{USD} 437,338$, and $\mathrm{W}=\mathrm{USD} 16.57$ per hour.

\section{Conclusion}

The article presents the core of the equitable remuneration theory, showing the theoretical formulas and their verification. The tools that made it possible to achieve theoretical formulas are primarily the second principle of thermodynamics. Understanding the category of capital and applying the principles of thermodynamics allowed to present the model of capital and identify the economic constant $\mathrm{p}=$ 0.08 [1/year], which is necessary in the account of human capital and fair remuneration. The discovery of the constant led to the understanding that work only reduces the destructive influences of the second principle, but does not directly increase capital. The only exception is increasing the capital from experience. The source of capital is Nature and its influences are estimated by the economic constant.

\section{References}

[1] Atkins, P. (2005). Galileo's finger: The ten great ideas of science. Poland: Dom Wydawniczy Rebis.

[2] Atkins, P. (2007). Four laws that drive the universe. New York: Oxford University Press.

[3] Bliss Ch., Cohen A.J., Harcourt G.C. (eds.) (2005). Capital Theory, Vol. 1-3. Bodmin, Cornwall: Edward Elgar Publishing Limited

[4] Dobija, M. (1998). How to place human resources into the balance sheet. Journal of Human Resource Costing \& Accounting, 3(1), 83-92.

[5] Dobija, M. (2007). Abstract nature of capital and money, [in:] L.M. Cornwall (Ed.), new developments in banking and finance (pp. 89-114). New York: Nova Science Publishers. https://doi.org/10.1108/eb029044.

[6] Goetzmann, W.N., \& Ibbotson, R.G. (2006). History and the Equity Risk Premium, [in:] Goetzmann W.N., Ibbotson R.G. (ed.), The Equity Risk Premium: Essays and Explorations, Yale School of Management, Oxford University Press.

[7] Pikulska-Robaszkiewicz, A. (1999). Usury in the state and law of Republican Rome (Polish language: Lichwa w państwie i prawie republikańskiego Rzymu), Wydawnictwo Uniwersytetu Łódzkiego, Łódź.

[8] Kozioł, W. (2011). Constant of potential growth in the calculation of human capital (Polish language: Stała potencjalnego wzrostu w rachunku kapitału ludzkiego), Nierówności Społeczne w Wzrost Gospodarczy, Uniwersytet Rzeszowski, Zeszyt nr 19, s. 252-260.

[9] Pacioli, L. (1494). Summa de arithmetica, geometría, proportioni et proportionalità, Vinegia: P. de Paganini, Wenecja. https://doi.org/10.5479/sil.440357.39088007406663.

[10] Kurek, B. (2011). The deterministic risk premium hypothesis, Cracow: Monografie, Wydawnictwo Uniwersytetu Ekonomicznego w Krakowie.

[11] Kurek, B. (2012). An estimation of the capital growth rate in business activities. Modern Economy, 3(4), 364-372. doi: 10.4236/me.2012.34047. https://doi.org/10.4236/me.2012.34047.

[12] Renkas, J. (2016). Wage inequalities and the economic constant of potential growth (Polish language: Nierówności płacowe a stała ekonomiczna potencjalnego wzrostu), Nierówności Społeczne a Wzrost Gospodarczy, Zeszyt nr 47(3), pp. 466-480, https://doi.org/10.15584/nsawg.2016.3.34.

[13] Renkas, J. (2013). Wage expectations in light of human capital measurement theory. Argumenta Oeconomica Cracoviensia, 9(9), 29-42. https://doi.org/10.15678/AOC.2013.0902. 